\title{
Peningkatan Kepatuhan Wajib Pajak melalui Penerapan Sistem e-filling yang Dimoderasi oleh Pemahaman Internet
}

\author{
Moch. Aminnudin ${ }^{1}$, Ali $^{2}$, Subadriyah ${ }^{2}$ \\ Universitas Islam Nahdlatul Ulama Jepara ${ }^{1}$, \\ Universitas Islam Nahdlatul Ulama Jepara ${ }^{2}$ \\ Universitas Islam Nahdlatul Ulama Jepara ${ }^{3}$ \\ amin2udin@unisnu.ac.id ${ }^{1}$, ali@unisnu.ac.id ${ }^{2}$, , subadriyah@unisnu.ac.id ${ }^{3}$
}

\begin{abstract}
Taxes are the largest source of state revenue that has many roles. Until 2017 taxes can contribute $85.6 \%$ of state revenues. The level of taxpayer compliance in Indonesia is quite alarming and continues to decline, in 2011 taxpayer compliance could reach $97.2 \%$, but in 2014 it fell to 91.6\%, and again in 2015 only 82\%. The purpose of this study was to determine the effect of the implementation of the efilling system on taxpayer compliance and to know the relationship between the application of e-filling systems and taxpayer compliance which was moderated by internet understanding. The initial step as the main basis of research is by collecting data. Primary data obtained from the distribution of questionnaires. All taxpayers registered with the Tax Office as the study population. Determination of the sample was obtained by the Slovin formula so that 100 respondents were obtained. The analysis method uses simple linear regression and the Moderated Regression Analysis (MRA) method. The results obtained are that the application of e-filling system has a significant effect on taxpayer compliance and internet understanding is able to moderate the relationship between the application of e-filling systems to taxpayer compliance.
\end{abstract}

Keywords: E-filling, Taxpayer Compliance, Internet Understanding

\begin{abstract}
Abstrak
Pajak sebagai sumber penerimaan negara terbesar yang memiliki banyak peranan.. Hingga tahun 2017 pajak mampu menyumbang 85,6\% dari pendapatan negara. Tingkat kepatuhan wajib pajak di Indonesia cukup memprihatinkan dan terus mengalami penurunan, tahun 2011 kepatuhan wajib pajak bisa mencapai 97,2\%, namun tahun 2014 turun menjadi 91,6\%, dan turun lagi di tahun 2015 hanya 82\%. Tujuan penelitian ini adalah mengetahui pengaruh dari penerapan sistem efilling terhadap kepatuhan wajib pajak dan mengetahui hubungan penerapan sistem e-filling dengan kepatuhan wajib pajak yang dimoderasi oleh pemahaman internet. Langkah awal sebagai dasar utama penelitian yaitu dengan pengumpulan data. Data primer diperoleh dari penyebaran kuisioner. Seluruh wajib pajak yang terdaftar di Kantor Pajak sebagai populasi penelitian. Penentuan sampel diperoleh dengan rumus slovin sehingga didapat 100 responden. Metode analisis menggunakan regresi linier sederhana dan metode Moderated Regression Analysis (MRA). Hasil yang diperoleh yaitu penerapan system e-filling berpengaruh signifikan terhadap kepatuhan wajib pajak dan pemahaman internet mampu memoderasi hubungan antara penerapan system e-filling terhadap kepatuhan wajib pajak.
\end{abstract}

Kata Kunci: E-filling, Kepatuhan Wajib Pajak, Pemahaman Internet 


\section{PENDAHULUAN}

Pembangunan nasional merupakan salah satu sumber yang dibiayai oleh pajak. Pajak sebagai sumber dari penerimaan negara terbesar yang memiliki banyak peranan. Peranan pajak tersebut dapat dirasakan secara langsung ataupun secara tidak langsung. Pentingnya peran pajak dalam pembangunan nasional memerlukan peningkatan dalam penerimaan pajak. Hingga tahun 2017 pajak mampu menyumbang 85,6\% dari pendapatan negara (http://www.kemenkeu.go.id). Nilai tersebut menjadi nilai tertinggi dibandingkan dengan tahun 2015 dan tahun 2016 yang hanya berada pada kisaran 83\%.

Pajak didapat dari masyarakat dengan metode self assessment. Sistem self assessment ini memberikan kepercayaan kepada WP untuk menghitung serta melaporkan secara mandiri pajak yang terutang sedangkan petugas pajak hanya mengawasinya. Sistem ini tentunya sangat bergantung terhadap kesadaran WP dalam menjalankan kewajiban perpajakannya, dimana terdapat banyak WP yang lalai akan kewajibannya dalam melaporkan dan membayar pajak. Prosentase kepatuhan wajib pajak di Indonesia cukup memprihatinkan dan terus mengalami penurunan, tahun 2011 kepatuhan wajib pajak bisa mencapai 97,2\%, namun tahun 2014 turun menjadi 91,6\%, dan turun lagi di tahun 2015 hanya 82\% (Subadriyah \& Aliyah, 2018). Tinggi rendahnya kepatuhan wajib pajak tersebut disebabkan oleh kesadaran wajib pajak untuk membayar pajak tepat waktu. Hal ini terjadi karena kurangnya pengetahuan dari wajib pajak (tax payer) dalam menjalankan kewajibannya dan bukan sebuah unsur kesengajaan (Suyanto, Intansari, \& Endahjati, 2016). Ketidakpahaman yang mengkibatkan tidak melakukan pelaporan dan pembayaran pajak dapat dikategorikan sebagai perlawanan pajak (tax evasion) yang bersifat pasif (Ayu R \& Hastuti, 2009).

Berbagai cara telah dilakukan Direktorat Jenderal Pajak agar prosentase kepatuhan wajib pajak terus mengalami peningkatan. Salah satu cara tersebut yaitu dengan menciptakan kemudahan dalam penyampaian SPT. Reformasi perpajakan adalah cara yang dilakukan dirjen pajak dengan strategi membuat terobosan dalam penyampaian SPT melalui sistem elektronik dengan memanfaatkan internet dalam penyampaiannya. Langkah ini diambil karena pemakai internet semakin meningkat setiap tahunnya. Bentuk reformasi administrasi perpajakan tersebut adalah dengan menerapkan sistem administrasi modern yang disebut e-filling. Internet menjadi media pendukung dalam penyampaian lewat $e$-filling, dalam penggunaan tersebut dibutuhkan pemahaman internet yang baik, karena dengan pemahaman internet yang baik akan semakin tinggi keinginan wajib pajak untuk menyampaikan SPT lewat $e$-filling.

Penelitian yang dilakukan di Dinas Peindustrian dan Perdagangan DIY memberikan hasil bahwa penerapan sistem $e$-filling memiliki pengaruh yang cukup signifikan terhadap kepatuhan wajib pajak dan pemahaman internet tidak dapat memoderasi adanya pengaruh penerapan sistem $e$-filling terhadap kepatuhan WP OP PNS (Lado \& Budiantara, 2018). Penerapan 
sistem e-filling juga mempengaruhi kepatuhan WP Orang Pribadi di KPP Pratama Bukittinggi. Selain itu pemahaman internet memiliki pengaruh terhadap hubungan penerapan sistem e-filling dengan kepatuhan WP OP (Novariyanti, Herawati, \& Hamdi, 2016). E-filling mempu memberikan kemudahan, keamanan dan kredibilitas kepada masyarakat yang menggunakan e-filling (Moorthy, Suhaily, Suhaili, Syazwani, \& Chelliah, 2014). Adapun perumusan masalah yang harus dipecahkan yaitu apakah penerapan sistem $e$-filling berpengaruh signifikan terhadap kepatuhan wajib pajak? dan apakah pemahaman internet mampu memoderasi hubungan penerapan sistem e-filling dengan kepatuhan WP? Tujuan penelitian ini adalah mengetahui pengaruh dari penerapan sistem efilling terhadap kepatuhan wajib pajak dan mengetahui hubungan penerapan sistem $e$-filling dengan kepatuhan wajib pajak yang dimoderasi oleh pemahaman internet.

\section{KAJIAN LITERATUR}

\section{Kepatuhan Wajib Pajak}

Kepatuhan wajib pajak merupakan kondisi dimana WP dapat memenuhi segala kewajiban serta melaksanakan kewajiban perpajakannya (Rahman, 2010). Selanjutnya kepatuhan pajak digolongkan menjadi dua, yaitu kepatuhan pajak formal dan material. Kepatuhan pajak formal merupakan kepatuhan yang berkaitan dengan pemenuhan undang-undang, diantaranya telah mendaftar NPWP, tidak memiliki utang pajak serta melaporkan SPT Masa dan Tahunan dengan tepat waktu. Sedangkan kepatuhan pajak material merupakan adalah kondisi saat WP secara substantif memenuhi semua isi undang-undang perpajakan (Hutasoit, 2017).

Cara yang dilakukan agar WP semakin meningkat dengan administrasi perpajakan yaitu 1) melakukan rencana program beserta kegiatan yang mampu menyadarkan sekaligus meningkatkan kepatuhan secara suka rela. 2). Meningkatkan pelayanan terhadap WP yang telah patuh supaya dapat meningkatkan kepatuhannya. 3). Menggunakan program atau kegiatan yang mampu memerangi ketidakpatuhan.

\section{Pemahaman Internet}

Internet merupakan sistem informasi yang berbasis komputer dan merupakan jaringan komputer yang saling terkoneksi. Setiap jaringan computer mampu mencakup puluhan, ratusan, hingga ribuan komputer dan membuat mereka saling berbagi informasi satu sama lain dan juga berbagi sumber-sumber daya komputerisasi seperti data base informasi dan super computer (Lado \& Budiantara, 2018).

Internet memiliki manfaat bagi kehidupan sehari-hari, informasi yang disajikan sangat berguna dan sangat dibutuhkan oleh para pengguna. Kegunaan tersebut terlihat dengan adanya internet para pengguna dapat dengan mudah, cepat serta aman dalam menggunakan $e$-filling. Selain itu internet adalah salah satu sumber pengetahuan bagi kehidupan. Dengan 
adanya internet mampu mempermudah WP dalam mengetahui peraturanperaturan serta perundang-undangan dalam perpajakan.

\section{Sistem E-Filling}

E-filling merupakan cara penyampaian SPT dengan menggunakan internet melalui website DJP. Sehingga WP tidak perlu mencetak seluruh formulir laporan serta menunggu untuk mendapatkan tanda terima manual (Gita, 2010). Dalam sistem e filling menyediakan beberapa panduan untuk pembayaran pajak atas informasi yang benar untuk disertakan pengembalian pajak mereka, selain itu sistem ini juga mampu menghitung jumlah pajak yang dinilai berdasarkan informasi yang disediakan. Dapat disimpulkan bahwa e-filling merupakan sistem informasi yang membantu pengguna (pembayar pajak) untuk mengirimkan laporan SPT secara online menggunakan internet dan dilakukan secara real time (Andriani, Napitupulu, \& Haryaningsih, 2017).

Tujuan adanya e-filling yaitu agar mencapai transparansi serta menghilangkan praktik KKN. Adanya e-filling ini mampu memudahkan dan mempercepat WP dalam pelaporan SPT, hal ini dikarenakan WP tidak perlu pergi ke Kantor Pajak untuk mengirimkan data SPT.

\section{Penelitian Terdahulu}

Terdapat beberapa penelitian yang telah membahas mengenai penerapan sistem e-filling ini. Penelitian yang dilakukan di Dinas Perndustrian dan Perdagangan DIY memberikan hasil bahwa penerapan sistem $e$-filling mempengaruhi secara signifikan terhadap kepatuhan WP dan pemahaman internet tidak dapat memoderasi adanya pengaruh dari penerapan sistem e-filling terhadap kepatuhan WP OP PNS (Lado \& Budiantara, 2018). Penerapan sistem $e$-filling juga mempengaruhi kepatuhan WP Orang Pribadi di KPP Pratama Bukittinggi. Selain itu pemahaman internet memiliki pengaruh terhadap hubungan antara penerapan sistem efilling dengan kepatuhan WP OP (Novariyanti et al., 2016). E-filling mempu memberikan kemudahan, keamanan dan kredibilitas kepada masyarakat yang menggunakan e-filling (Moorthy et al., 2014) Persepsi kemudahan pengguanaan, kesukarelaan menggunakan, sikap terhadap penggunaan dan norma subyektif merupakan faktor yang dapat mempengaruhi perlaku penerimaan WP terhadap e-filling. E-filling dapat diterima sebagai sistem pelaporan yang dilakukan secara online dan juga realtime (Susanto, 2011).

Kualitas sistem serta kualitas layanan adalah hal yang paling mempengaruhi pengguna untuk menggunakan sistem e-filling. Ini dapat disebabkan oleh sifat sistem jenis ini sebagai sistem layanan berbasis elektronik, di mana jarak pandang dan keamanan sebagai bagian dari kualitas biasanya sebagian besar dipertimbangkan oleh pengguna (Andriani et al., 2017). 


\section{Alur Kerangka Pemikiran}

Berdasarkan tinjauan dan latar belakang di atas maka kerangka penelitian disajikan pada gambar dibawah ini.

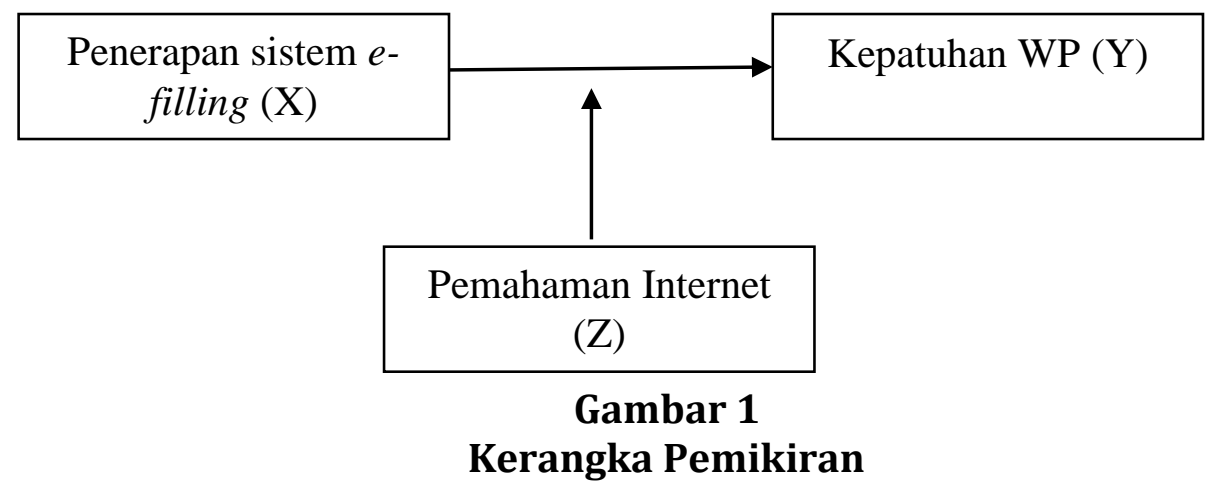

Penelitian dalam bidang perpajakan telah banyak dilakukan. (Jotopurnomo \& Yenni, 2013) melakukan penelitian tentang kualitas pelayanan fiskus. Langkah ini sebagai upaya yang dilakukan agar prosentase kepatuhan WP dapat meningkat. Seiring berjalannya waktu, pajak melakukan modernisasi sistem perpajakan. Salah satunya yaitu dengan melakukan sosialisasi perpajakan. Pemahaman pajak sangat penting untuk ditingkatkan agar kesadaran dalam melaksanakan kewajiban perpajakan meningkat. Adanya tax amnesty juga sebagai upaya peningkatan kepatuhan. (Husnurrosyidah, 2016) menyebutkan bahwa adanya tax amnesty memberikan pengampunan dengan penghapusan nilai pajak terutang dan penghapusan denda serta sanksi, sehingga mempengaruhi kepatuhan wajib pajak.

Pemerintah terus berupaya untuk meningkatkan pajak dengan melakukan berbagai macam reformasi adminstrasi perpajakan diantaranya yaitu penerapan sistem $e$-filling. Tujuan sistem ini adalah memudahkan dan mempercepat WP untuk pelaporan SPT, karena WP tidak lagi datang ke Kantor Pajak untuk mengirimkan data SPT. Adapun roadmap dalam penelitian ini disajikan dalam gambar dibaawah ini.

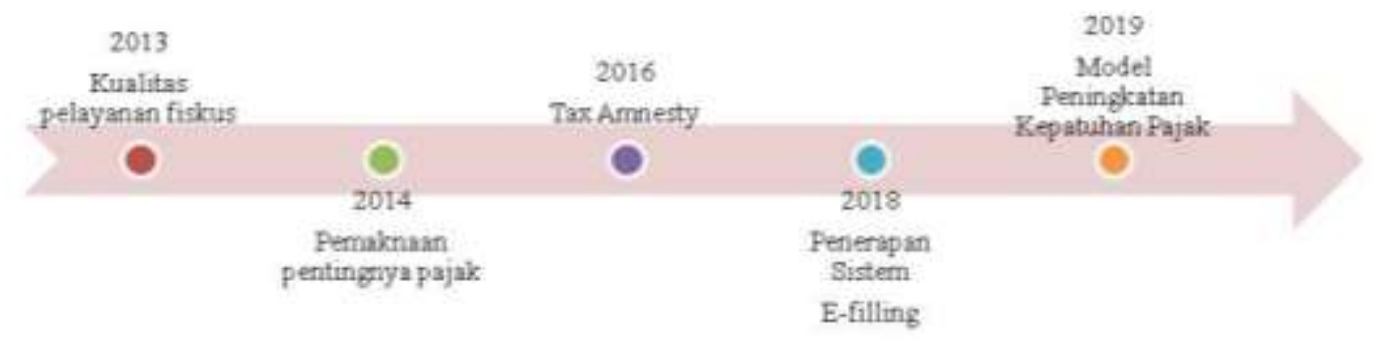

Gambar 2

Roadmap Penelitian

\section{Hipotesis}

E-filling merupakan salah atu bagian dari reformasi pajak yang mempunyai tujuan untuk memudahkan dalam pembuatan dan pelaporan 
SPT kepada DJP. Sistem e-filling ini ditetapkan oleh DJP sebagi upaya dalam mengoptimalkan pelayanan dan adanya $e$-filling ini diharapkan memberikan manfaat kemudahan, kenyamanan dan kepuasan kepada WP, sehingga meningkatkan kepatuhan.

Sistem e-filling memberikan manfaat kemudahan dan kenyamanan bagi WP dalam penyampaian SPT dengan jaringan koneksi internet. Sistem ini dapat digunakan dengan ketentuan WP harus mengerti cara mengoperasikan internet. Apabila WP tidak dapat mengoperasikannya, maka penerapan sistem tersebut tidak memiliki pengaruh apa-apa terhadap kenyamanan serta kemudahan dalam menyampaikan SPT. Semakin tinggi tingkat pemahaman WP terhadap internet maka semakin tinggi tingkat penggunaan sistem $e$-filling .

Berdasarkan penelitian terdahulu memperoleh hasil bahwa penerapan sistem e-filling mempengaruhi secara signifikan terhadap kepatuhan WP dan pemahaman internet tidak dapat memoderasi adanya pengaruh dari penerapan sistem e-filling terhadap kepatuhan WP OP PNS (Lado \& Budiantara, 2018). Penerapan sistem e filling juga mempengaruhi kepatuhan WP Orang Pribadi di KPP Pratama Bukittinggi. Selain itu pemahaman internet memiliki pengaruh terhadap hubungan antara penerapan sistem e-filling dengan kepatuhan WP OP (Novariyanti et al., 2016). E-filling mempu memberikan kemudahan, keamanan dan kredibilitas kepada masyarakat yang menggunakan e-filling (Moorthy et al., 2014) Persepsi kemudahan pengguanaan, kesukarelaan menggunakan, sikap terhadap penggunaan dan norma subyektif merupakan faktor yang dapat mempengaruhi perlaku penerimaan WP terhadap e-filling. E-filling dapat diterima sebagai sistem pelaporan yang dilakukan secara online dan juga realtime (Susanto, 2011).

Kualitas sistem serta kualitas layanan adalah hal yang paling mempengaruhi pengguna untuk menggunakan sistem e-Filing. Ini dapat disebabkan oleh sifat sistem jenis ini sebagai sistem layanan berbasis elektronik, di mana jarak pandang dan keamanan sebagai bagian dari kualitas biasanya sebagian besar dipertimbangkan oleh pengguna (Andriani et al., 2017).

H1 : Penerapan Sistem E-Filling berpengaruh signifikan terhadap Kepatuhan WP

H2 : Penerapan Sistem E-Filling berpengaruh signifikan terhadap Kepatuhan WP yang dimoderasi oleh Pemahaman Internet

\section{METODE PENELITIAN Jenis Penelitian}

Penelitian ini merupakan penelitian kuantitatif. Dimana penelitin ini diperoleh dari sumber pertama dengan penyebaran kuisioner. Penelitian ini akan menganalisis pengaruh penerapan sistem e-filling terhadap kepatuhan wajib pajak dengan dimoderasi oleh pemahaman internet. 


\section{Variabel Penelitian dan Definisi Operasional Variabel}

Variabel dalam penelitian ini terdiri dari variable independen dan variable dependen serta variable moderasi. Variabel independen yang digunakan yaitu penerapan sistem $e$-filling. Penerapan system e-filling yaitu bagian dari suatu system administrasi perpajakan modern yang digunakan untuk menyampaikan surat pemberitahuan WP secara elektronik kepada DJP melalui sistem online yang real time dengan memanfaatkan internet (Nurhidayah, 2015). Sedangkan variable dependen yaitu kepatuhan wajib pajak. Kepatuhan pajak merupakan suatu keadaan dimana saat wajib pajak dapat memenuhi semua kewajiban perpajakan dan melaksanakan hak perpajakannya. Lebih lanjut kepatuhan pajak dibagi menjadi dua yaitu 1) kepatuhan pajak formal dan 2) kepatuhan pajak material (Hutasoit, 2017). Sedangkan untuk variable pemoderasinya yaitu pemahaman internet. Pemahaman internet diartikan sebagai mengerti betul tentang apa itu internet dan juga mengetahui bagaimana cara menggunakannya (Nurhidayah, 2015).

\section{Tabel 1}

Definisi Operasional Variabel

\begin{tabular}{|c|c|c|c|c|}
\hline No & Variabel & Definisi & Indikator & Skala \\
\hline 1 & $\begin{array}{l}\text { Penerapan } \\
\text { Sistem } E \text { - } \\
\text { filling }(\mathrm{X})\end{array}$ & $\begin{array}{l}\text { Bagian dari suatu } \\
\text { system administrasi } \\
\text { perpajakan modern } \\
\text { yang digunakan untuk } \\
\text { menyampaikan surat } \\
\text { pemberitahuan WP } \\
\text { secara elektronik } \\
\text { kepada DJP melalui } \\
\text { system online yang } \\
\text { realtime dengan } \\
\text { memanfaatkan internet } \\
\text { (Nurhidayah, 2015) }\end{array}$ & $\begin{array}{l}\text { 1) Kecepatan } \\
\text { Pelaporan SPT; } \\
\text { 2) Perhitungan } \\
\text { Lebih Cepat; } \\
\text { 3) Kemudahan } \\
\text { pengisian SPT; } \\
\text { 4) Kelengkapan data } \\
\text { pengisian SPT; } \\
\text { 5) Leboh ramah } \\
\text { lingkungan; } \\
\text { 6) Tidak merepotkan }\end{array}$ & Likert \\
\hline 2 & $\begin{array}{l}\text { Kepatuhan } \\
\text { Wajib Pajak } \\
\text { (Y) }\end{array}$ & $\begin{array}{l}\text { Keadaan dimana saat } \\
\text { wajib pajak dapat } \\
\text { memenuhi semua } \\
\text { kewajiban perpajakan } \\
\text { dan melaksanakan hak } \\
\text { perpajakannya. Lebih } \\
\text { lanjut kepatuhan pajak } \\
\text { dibagi menjadi dua } \\
\text { yaitu 1) kepatuhan } \\
\text { pajak formal dan 2) } \\
\text { kepatuhan pajak } \\
\text { material (Hutasoit, } \\
\text { 2017). }\end{array}$ & 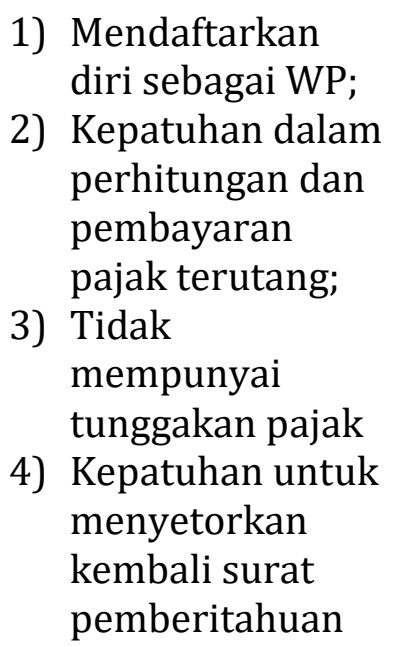 & Likert \\
\hline 3 & Pemahaman & Mengerti betul tentang & 1) Memperoleh & Likert \\
\hline
\end{tabular}


Moch. Aminnudin dkk

\begin{tabular}{|c|c|c|c|}
\hline Internet (Z) & $\begin{array}{l}\text { apa itu internet dan } \\
\text { juga mengetahui } \\
\text { bagaimana cara } \\
\text { menggunakannya } \\
\text { (Nurhidayah, 2015) }\end{array}$ & 2) & $\begin{array}{l}\text { informasi; } \\
\text { Menambah } \\
\text { pengetahuan } \\
\text { Kecepatan } \\
\text { mengakses }\end{array}$ \\
\hline
\end{tabular}

\section{Populasi, Sampel dan Teknik Pengambilam Sample}

Seluruh WP orang pribadi mapun badan yang berada di Kabupaten Jepara yang berjumlah 52.512 adalah populasi penelitian ini. Seluruh populasi tersebut kemudian dipersempit lagi dengan cara menghitung ukuran sampel menggunakan rumus slovin.

$$
\mathrm{n}=\frac{\mathrm{N}}{1+\mathrm{N}(\mathrm{e})^{2}}
$$

Keterangan:

$\mathrm{n} \quad=$ Ukuran Sampel,

$\mathrm{N} \quad=$ Ukuran Populasi,

e $\quad=$ Presentase kelonggaran ketelitian kesalahan pengambilan sampel yang masih bisa ditolerir $(\mathrm{e}=0,1)$.

Untuk mengetahui sampel penelitian, dapat dilakukan perhitungan sebagai berikut:

$$
\begin{aligned}
& n=\frac{52.512}{1+52.512 \cdot(0,1)^{2}} \\
& n=\frac{52.512}{526,12}
\end{aligned}
$$

$$
\mathrm{n}=99,8
$$

Berdasarkan perhitungan diatas maka diketahui sampel yang diambil adalah 100 responden. Sampel tersebut diperoleh dengan menggunakan teknik simple random sampling.

\section{Metode Pengumpulan Data}

Langkah selanjutnya yaitu metode pengumpulan data. Data dikumpulkan dengan membagikan kuisioner kepada responden. Kuisioner ini diukur dengan skala likert.

\section{Metode Analisis}

Pengujian dilakukan dengan uji kualitas data menggunakan uji validitas dan uji reliabilitas. Metode analisis yang digunakan adalah analisis regresi linier sederhana yang didasarkan pada hubungan kausal antara satu variabel dependen dan satu variabel independen. Hasil yang diharapkan dengan uji regresi ini yaitu untuk mengetahui pengaruh penerapan sistem e filling terhadap kepatuhan wajib pajak dengan dimoderasi oleh pemahaman internet. Adapun persamaannya yaitu:

$\mathrm{Y}=\alpha+\beta \mathrm{X}+\mathrm{e}$ 
Pengujian regresi tersebut dilakukan setelah model dalam penelitian ini lolos dari uji asumsi klasik. Pendekatan analitik yang digunakan dalam mengontrol pengaruh dari variabel pemoderasi menggunakan metode Moderated Regression Analysis (MRA) (Ghozali, 2011). Adapun persamaannya adalah sebagai berikut

$$
\begin{aligned}
& =\mathrm{a}+\mathrm{b} 1 \mathrm{Xi}+\mathrm{e} \\
& \mathrm{Yi} \quad=\mathrm{a}+\mathrm{b} 1 \mathrm{Xi}+\mathrm{e} \ldots \ldots \ldots \ldots \ldots \ldots \ldots(1) \\
& \mathrm{Yi} \quad=\mathrm{a}+\mathrm{b} 1 \mathrm{Xi}+\mathrm{b} 2 \mathrm{Zi}+\mathrm{b} 3 \mathrm{Xi}^{*} \mathrm{Zi}+\mathrm{e} . .(3) \\
& \text { Dimana: } \\
& \text { Yi : Kepatuhan WP } \\
& \text { a : Konstanta } \\
& \text { b : Koefisien arah pers. penelitian } \\
& \mathrm{X} \text { : Penerapan sistem e-filling } \\
& \mathrm{Z} \text { : Jenis variabel moderator } \\
& \text { e : variabel pengganggu }
\end{aligned}
$$

Apabila dalam persamaan ke 2 dan 3 tidak berbeda secara signifikan maka Z bukanlah variabel moderator tetapi sebagai variabel independen.

\section{PEMBAHASAN \\ Deskripsi Responden}

Data profil respoden dalam penelitian ini dideskripsikan berdasarkan karakteristik demografis menurut jenis kelamin, usia responden, tingkat pendidikan, pekerjaan, dan pengetahuan pajak. Berdasarkan data yang diterima, dapat ditampilkan hasil sebagai berikut:

\begin{tabular}{crr}
\multicolumn{3}{c}{ Tabel 2 } \\
Jenis Kelamin \\
\hline $\begin{array}{c}\text { Jenis } \\
\text { Kelamin }\end{array}$ & $\begin{array}{c}\text { Jumlah } \\
\text { Responden }\end{array}$ & Persentasi \\
\hline Laki-laki & 57 & $57 \%$ \\
Perempuan & 43 & $43 \%$ \\
Total & 100 & $100 \%$ \\
Sumber: Data Primer yang diolah, 2019
\end{tabular}

Hasil diatas menunjukkan bahwa responden laki-laki lebih tinggi dibandingkan responden perempuan dengan perbedaan sebesar $14 \%$. Hal ini menunjukkan bahwa perbedaan penggunaan e-filling antara laki-laki dan perempuan tidak terpaut jauh.

Usia responden yang ikut berpartisipasi pun beragam jumlahnya dan tidak ada yang mendominasi. Responden terbanyak adalah sebesar $40 \%$ dari wajib pajak berusia antara 25 sampai dengan 35 tahun. Usia 35 sampai dengan 45 tahun sebesar 37\%. Dari total keseluruhan responden yaitu 100 
responden terdapat responden yang berusia diatas 55 tahun yaitu sebesar 8\%. Hal ini berarti partisipasi aktif masyarakat dalam memenuhi kewajiban perpajakannya yaitu dengan melakukan pelaporan SPT.

Tabel 3

Usia Responden

\begin{tabular}{lrr}
\hline $\begin{array}{l}\text { Usia } \\
\text { Responden }\end{array}$ & $\begin{array}{c}\text { Jumlah } \\
\text { Responden }\end{array}$ & Persentasi \\
\hline 25-35 Tahun & 40 & $40 \%$ \\
35-45 Tahun & 37 & $37 \%$ \\
45-55 Tahun & 15 & $15 \%$ \\
>55 Tahun & 8 & $8 \%$ \\
Total & 100 & $100 \%$ \\
\hline Sumber: Data Primer yang diolah, 2019
\end{tabular}

Sedangkan jika dilihat dari statistic tingkat pendidikan responden, menunjukkan hasil bahwa tingkat pendidikan didominasi oleh sarjana yaitu sebesar 38\%. Sedangkan pendidikan lainnya seperti doctor jumlah responden hanya 4\%. Selanjutnya adalah diploma dengan $26 \%$, kemudian SMA sebesar 24\% dan terakhir Magister 8\%.

\section{Tabel 4}

Pendidikan Responden

\begin{tabular}{lrr}
\hline $\begin{array}{c}\text { Pendidikan } \\
\text { Responden }\end{array}$ & $\begin{array}{c}\text { Jumlah } \\
\text { Responden }\end{array}$ & Persentasi \\
\hline SMA & 24 & $24 \%$ \\
Diploma & 26 & $26 \%$ \\
Sarjana & 38 & $38 \%$ \\
Magister & 8 & $8 \%$ \\
Lainnya & 4 & $4 \%$ \\
Total & 100 & $100 \%$ \\
\hline Sumber: Data Primer yang diolah, 2019
\end{tabular}

Selain itu statistic yang perlu ditampilkan yaitu Jenis pekerjaan responden. Kebanyakan responden yaitu wirausaha sebesar 40\%. Wirausaha disini yang paling banyak adalah mereka yang menjalankan usaha pribadi maupun bukan. Karena mereka harus memenuhi kewajiban-kewajiban perpajakan yang salah satunya melaporkan kegiatan usaha mereka dalam bentuk laporan bulanan maupun laporan tahunan. Dan jika dibandingkan dengan data pendidikan responden dapat dilihat bahwa kebanyakan responden adalah dari lulusan sarjana. Hal ini kebanyakan para wiirausaha berstatus lulusan sarjana. Selanjutnya yaitu PNS sebesar 28\%, dilanjutkan swasta $25 \%$ dan terakhir lainnya sebesar $7 \%$ yang terdiri dari dokter, pedagang kelontong, warung makan dan perawat. 
Tabel 5

Pekerjaan Responden

\begin{tabular}{lrr}
\hline $\begin{array}{c}\text { Pekerjaan } \\
\text { Responden }\end{array}$ & $\begin{array}{c}\text { Jumlah } \\
\text { Responden }\end{array}$ & Persentasi \\
\hline PNS & 28 & $28 \%$ \\
Swasta & 25 & $25 \%$ \\
Wirausaha & 40 & $40 \%$ \\
Lainnya & 7 & $7 \%$ \\
Total & 100 & $100 \%$ \\
\hline \multicolumn{2}{c}{ Sumber: Data primer yang diolah, 2019}
\end{tabular}

Statistik lainnya yang perlu dibahas yaitu mengenai pengetahuan pajak responden. Kebanyakan responden tidak memiliki pengetahuan mengenai perpajakan, hal ini dapat dilihat dari jumlah responden sebesar $43 \%$. Ketidaktahuan wajib pajak ini yang menjadikan banyaknya wajib pajak yang belum dapat menggunakan fasilitas-fasilitas perpajakan seperti sistem e-filling. Sehingga mengakibatkan menurunnya kelalaian akan kewajiban perpajakannya dan membuat kepatuhan wajib pajak menjadi menurun. Selanjutnya yaitu wajib pajak dengan pengetahuan yang diperoleh dari penyuluhan perpajakan sebesar 29\%, kemudian wajib pajak yang didapat dari pengetahuan brevet sebesar 18\% dan yang terakhir pengetahuan wajib pajak yang diperoleh dari sumber lainnya yaitu $10 \%$ dari jumlah responden.

Tabel 6

Pengetahuan Pajak

\begin{tabular}{lcc}
\hline $\begin{array}{l}\text { Pengetahuan } \\
\text { Pajak } \\
\text { Responden }\end{array}$ & $\begin{array}{c}\text { Jumlah } \\
\text { Responden }\end{array}$ & \begin{tabular}{l} 
Persentasi \\
\hline Brevet
\end{tabular} \\
$\begin{array}{l}\text { Penyuluhan } \\
\text { Pajak }\end{array}$ & 29 & $18 \%$ \\
Tidak Ada & & $29 \%$ \\
Lainnya & 43 & $43 \%$ \\
Total & 10 & $10 \%$ \\
Sumber: Data Primer yang diolah, 2019 &
\end{tabular}

\section{Uji Kualitas Data}

Uji Validitas

Uji validitas digunakan untuk mengukur kualitas kuisioner yang digunakan sebagai instrumen suatu penelitian atau digunakan untuk mengukur valid atau tidak suatu kuisioner.

Dasar pengambilan keputusan dilakukan dengan membandingkan nilai $r$ hitung dengan $r$ tabel, untuk $d f=n-2$. Dalam hal ini $n$ adalah jumlah 
sampel, jumlah sampel dalam penelitian ini adalah 100. Sehingga dapat dihitung $\mathrm{df}=\mathrm{n}-2=100-2=98$, untuk $\alpha=0,05$. Sehingga dapat diketahui $\mathrm{r}$ tabelnya sebesar 0,1966 . Uji validitas ini dilihat pada nilai corrected itemtotal correlation pada hasil SPSS. Hasil uji validitas dalam penelitian ini dapat disajikan dalam tabel berikut:

\section{Tabel 7}

\section{Uji Validitas}

\begin{tabular}{|c|c|c|c|c|}
\hline Variabel & Pertanyaan & rhitung & $\mathbf{r}_{\text {tabel }}$ & Keterangan \\
\hline Penerapan Sistem & $\mathrm{X} 1.1$ & 0,222 & 0,1966 & Valid \\
\hline \multirow[t]{12}{*}{ E-Filling } & $\mathrm{X} 1.2$ & 0,215 & 0,1966 & Valid \\
\hline & $\mathrm{X} 1.3$ & 0,354 & 0,1966 & Valid \\
\hline & $\mathrm{X} 1.4$ & 0,213 & 0,1966 & Valid \\
\hline & $\mathrm{X} 1.5$ & 0.208 & 0,1966 & Valid \\
\hline & X1.6 & 0,271 & 0,1966 & Valid \\
\hline & $\mathrm{X} 1.7$ & 0,403 & 0,1966 & Valid \\
\hline & $\mathrm{X} 1.8$ & 0.270 & 0,1966 & Valid \\
\hline & $\mathrm{X} 1.9$ & 0.207 & 0,1966 & Valid \\
\hline & $\mathrm{X} 1.10$ & 0,219 & 0,1966 & Valid \\
\hline & $\mathrm{X} 1.11$ & 0,216 & 0,1966 & Valid \\
\hline & $\mathrm{X} 1.12$ & 0,265 & 0,1966 & Valid \\
\hline & $\mathrm{X} 1.13$ & 0,238 & 0,1966 & Valid \\
\hline \multirow[t]{6}{*}{$\begin{array}{l}\text { Pemahaman } \\
\text { Internet }\end{array}$} & X2.1 & 0.594 & 0,1966 & Valid \\
\hline & $\mathrm{X} 2.2$ & 0,660 & 0,1966 & Valid \\
\hline & $\mathrm{X} 2.3$ & 0,374 & 0,1966 & Valid \\
\hline & $\mathrm{X} 2.4$ & 0,224 & 0,1966 & Valid \\
\hline & $X 2.5$ & 0,407 & 0,1966 & Valid \\
\hline & $\mathrm{X} 2.6$ & 0,408 & 0,1966 & Valid \\
\hline \multirow[t]{9}{*}{ Kepatuhan WP } & Y.1 & 0,202 & 0,1966 & Valid \\
\hline & Y.2 & 0,197 & 0,1966 & Valid \\
\hline & Y.3 & 0,300 & 0,1966 & Valid \\
\hline & Y.4 & 0,403 & 0,1966 & Valid \\
\hline & Y.5 & 0,318 & 0,1966 & Valid \\
\hline & Y.6 & 0,264 & 0,1966 & Valid \\
\hline & Y.7 & 0,362 & 0,1966 & Valid \\
\hline & Y.8 & 0,335 & 0,1966 & Valid \\
\hline & Y.9 & 0,380 & 0,1966 & Valid \\
\hline
\end{tabular}

Sumber: Data Primer yang diolah, 2019

Berdasarkan hasil pengujian tersebut dapat diketahui bahwa masing-masing item yang digunakan untuk menyusun masing-masing 
kuisioner memiliki rhitung $>r_{\text {tabel. }}$ Hal ini berarti bahwa masing-masing item indikator adalah valid sehingga dapat digunakan untuk analisis selanjutnya.

\section{Uji Reliabilitas}

Uji reliabilitas merupakan alat yang digunakan untuk mengukur suatu kuisioner yang merupakan indikator dari suatu variabel. Tujuan uji reliabilitas ini yaitu untuk mengetahui kehandalan alat ukur yang digunakan. Untuk melihat handal atau tidaknya kuisioner maka digunakan uji statistik Cronbach's Alpha. Dasar pengambilan keputusannya yaitu jika nilai Cronbach's Alpha > 0,6 maka variabel tersebut dikatakan reliabel. berikut:

Hasil uji reliabilitas dalam penelitian ini disajikan dalam tabel

\section{Tabel 8}

\section{Uji Reliabilitas}

\begin{tabular}{lccc}
\hline \multicolumn{1}{c}{ Variabel } & $\begin{array}{c}\text { Cronbach's } \\
\text { Alpha }\end{array}$ & $\begin{array}{c}\text { Nilai } \\
\text { Standar }\end{array}$ & Keterangan \\
\hline Penerapan Sistem Efilling & 0.614 & 0.6 & Reliabel \\
Pemahaman Internet & 0.711 & 0.6 & Reliabel \\
Kepatuhan WP & 0.625 & 0.6 & Reliabel \\
\hline
\end{tabular}

Sumber: Data Primer yang diolah, 2019

Berdasarkan hasil pengujian pada tabel diatas dapat diketahui bahwa masing-masing variabel memiliki nilai Cronbach's Alpha > 0,6, sehingga dapat disimpulkan bahwa variabel-variabel dalam penelitian ini adalah reliabel.

\section{Uji Asumsi Klasik}

\section{Uji Normalitas}

Uji normalitas bertujuan untuk menguji apakah variabel bebas, variabel terikat atau keduanya berdistribusi normal atau tidak. Dalam penelitian ini uji normalitas diperoleh dengan menggunakan uji One's Sample Kolmogorov-Smirnov Test. Apabila nilai sig K-S >0,05, maka data berdistribusi dengan normal.

Hasil uji normalitas dalam penelitian ini dapat disajikan dalam tabel berikut:

Tabel 9

\section{Hasil Uji Normalitas}

\begin{tabular}{cccc}
\hline Variabel & N & Sig & Keterangan \\
\hline $\begin{array}{c}\text { Unstandardized } \\
\text { Residual }\end{array}$ & 100 & 0.127 & Normal \\
\hline
\end{tabular}

Sumber : Data Primer yang diolah, 2019 
Berdasarkan table diatas dapat diketahui bahwa nilai probabilitas signifikansi sebesar 0,127. Hal ini berarti nilai tersebut lebih dari 0,05. Sehingga data berdistribusi normal. Dengan demikian model regresi layak digunakan untuk penelitian.

\section{Uji Multikolinieritas}

Uji multikolinieritas digunakan untuk mengetahui terdapat tidaknya korelasi antar variabel independen. Uji ini dilakukan dengan melihat nilai VIF dan Tolerance. Asumsinya jika nilai VIF $<10$ dan nilai Tolerance $>0,1$, maka tidak terjadi multikolinieritas. Hasil uji multikolinieritas dalam penelitian ini dapat disajikan dalam tabel berikut:

Tabel 10

\section{Hasil Uji Multikolinieritas}

\begin{tabular}{|c|c|c|c|}
\hline \multirow[t]{2}{*}{ Variabel } & & \multicolumn{2}{|c|}{ Collinearity Statistics } \\
\hline & & Tolerance & VIF \\
\hline $\begin{array}{l}\text { Penerapan Sistem } \\
\text { Filling }\end{array}$ & & 0.989 & 1.011 \\
\hline Pemahaman Internet & & 0.989 & 1.011 \\
\hline
\end{tabular}

Sumber: Data primer yang diolah, 2019

Berdasarkan tabel diatas menunjukkan bahwa nilai Tolerance masing-masing variabel lebih dari 0,1 , dan nilai VIF masing-masing variabel kurang dari 10. Sehingga dalam hal ini tidak terjadi multikolinieritas.

\section{Uji Heteroskedastisitas}

Uji ini memiliki tujuan untuk menguji apakah di dalam suatu model regresi terjadi ketidaksamaan variasi dari residual satu pengamatan ke pengamatan lain. Model regresi yang baik yaitu tidak terjadi heteroskedastisitas. Uji yang digunakan yaitu dengan Uji Grafik Scatterplot. Hasil pengujian heteroskedastisitas dalam penelitian ini dapat disajikan dalam gambar berikut: 


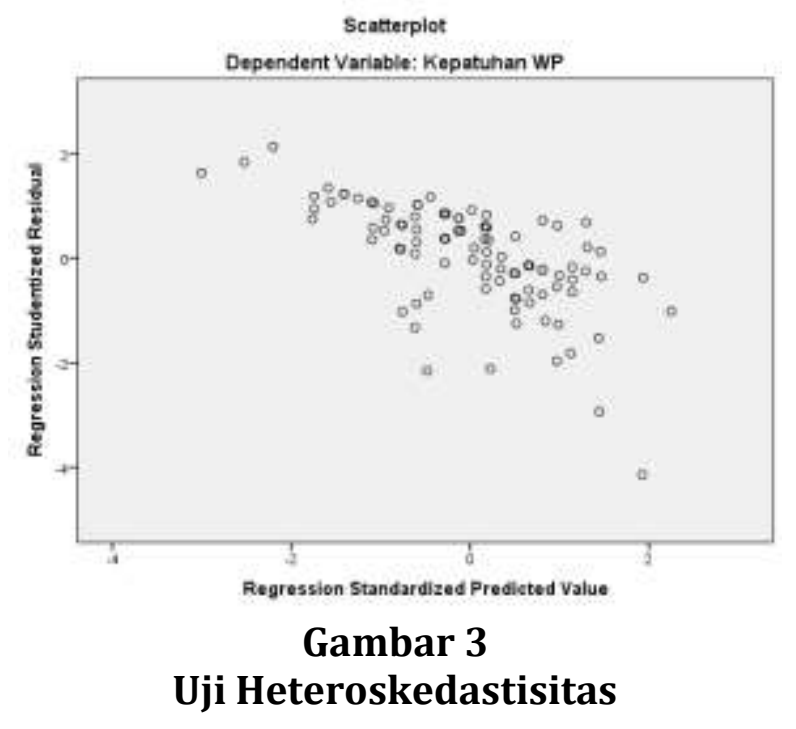

Berdasarkan diatas dapat diketahui bahwa tidak terdapat pola yang jelas seperti bergelombang, menyebar kemudian menyempit. Titiktitik tersebut menyebar diatas dan dibawah angka 0 pada sumbu Y. Sehingga dapat disimpulkan tidak terjadi heteroskedastisitas.

\section{Analisis Regresi Sederhana}

Analisis regresi sederhana digunakan untuk mengetahui pengaruh variabel independen yaitu penerapan sistem e-filling terhadap variabel dependen yaitu kepatuhan wajib pajak yang dimoderasi oleh pemahaman internet.

\section{Tabel 11 \\ Analisis Regresi}

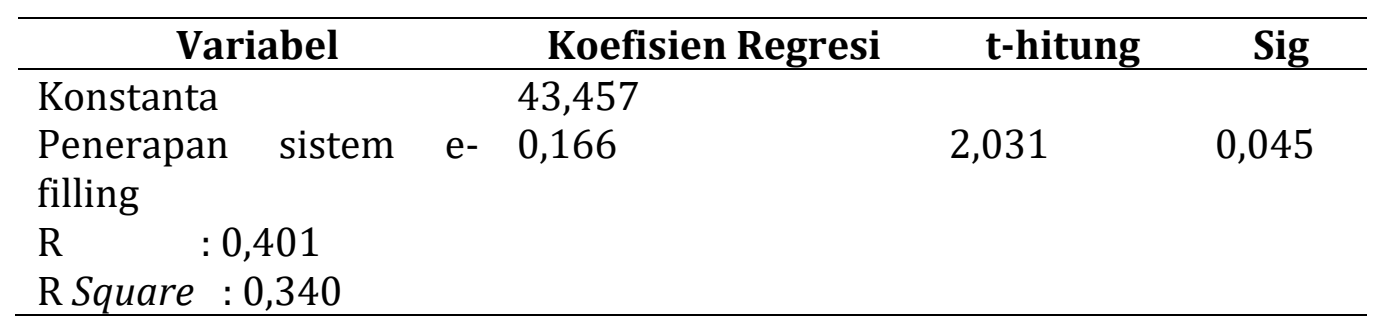

Sumber: Data Primer yang diolah, 2019

Berdasarkan hasil analisis regresi diatas, maka dapat disusun persamaan sebagai berikut:

$$
\mathrm{Y}=43.457+0,166 \mathrm{X}_{1}
$$

Hasil persamaan tersebut diperoleh koefisien regresi, dan dapat dijabarkan sebagai berikut:

Jika variable penerapan sistem e-filling (X1) konstan, maka akan dapat menaikkan variable kepatuhan wajib pajak (Y) sebesar 43,457. Sedangkan koefisien regresi variable $\mathrm{X}_{1}$ menunjukkan hasil yang positif hal ini berarti 
variable penerapan sistem e-filling berpengaruh positif terhadap kepatuhan wajib pajak dengan koefisien regresi sebesar 0.166. Hal ini menunjukkan jika penerapan sistem e-filling meningkat, maka kepatuhan wajib pajak akan meningkat.

\section{Uji Hipotesis Pertama (H1)}

H1 : Penerapan Sistem E-Filling berpengaruh signifikan terhadap Kepatuhan WP.

Uji t (uji parsial) ini digunakan untuk mengetahui besarnya pengaruh dari variable penerapan sistem e-filing terhadap kepatuhan wajib pajak. Berdasarkan table diatas diperoleh nilai t-hitung sebesar 2,031. Untuk mengetahui t-tabel dapat dicari dengan rumus $\mathrm{df}=\mathrm{n}-\mathrm{k}$. Dimana $\mathrm{n}$ adalah jumlah sampel, dan k adalah jumlah variabel. Dengan tingkat signifikansi $(\alpha)=0,05$. Jadi $\mathrm{df}=\mathrm{n}-\mathrm{k}=100-2=98$, maka diperoleh $\mathrm{t}$-tabel sebesar 1,984. Dengan demikian t-hitung $(2,031)>$ t-tabel $(1,984)$ dan nilai signifikansi $0,045<0,05$. Berdasarkan hal tersebut maka dapat disimpulkan bahwa penerapan sistem e-filling berpengaruh positif dan signifikan terhadap kepatuhan WP.

\section{Koefisien Determinasi}

Analisis koefisien determinasi digunakan untuk mengetahui tingkat pengaruh atau tingkat kepercayaan terhadap variabel yang dihitung atau untuk mengukur kemampuan variabel independen dalam menerangkan variasi perubahan variabel dependen. Berdasarkan hasil table diatas nilai $\mathrm{R}$ Square diperoleh hasil sebesar 0,340, dalam hal ini berarti bahwa variable independen mempunyai pengaruh positif dan signifikan serta dapat menjelaskan variable kepatuhan wajib pajak sebesar 34\%. Sedangkan sisanya 66\% dipengaruhi oleh factor lain yang tidak diseutkan dalam penelitian ini.

\section{Uji Hipotesis ke dua}

H2 : Penerapan Sistem E-Filling berpengaruh signifikan terhadap Kepatuhan WP yang dimoderasi oleh Pemahaman Internet.

Hipotesis ke dua ini diuji dengan menggunakan Moderate Regression Analysis (MRA). Adapun hasil pengujiannya dapat diliat pada table berikut ini :

Tabel 12

Analisis Regresi MRA

\begin{tabular}{ll}
\hline \multicolumn{1}{c}{ Variabel } & \multicolumn{1}{c}{ Koefisien Regresi } \\
\hline Konstanta & 108,253 \\
Penerapan Sistem E-Filling & $-1,509$ \\
Pemahaman Internet & $-2,818$ \\
M & 0,058 \\
R & 0,462 \\
\hline
\end{tabular}


Peningkatan Kepatuhan Wajib Pajak melalui Penerapan Sistem e-filling yang Dimoderasi oleh Pemahaman Internet

\begin{tabular}{ll}
\hline R Square & 0,368 \\
F Hitung & 9,349 \\
Sig F & 0,017 \\
Sig Penerapan Sistem E-filling & 0,022 \\
Sig Pemahaman Internet & 0,000 \\
Sig M & 0,005 \\
\hline
\end{tabular}

Sumber: Data primer yang diolah, 2019

Berdasrkan hasil analisis MRA, maka di dapat disusun persamaan untuk hipteis kedua yaitu:

$\mathrm{Y}=108,253-1,509 \mathrm{X}_{1}-2,818 \mathrm{Z}+0,058 \mathrm{X}_{1} \mathrm{Z}$

Berdasarkan persamaan tersebut diperoleh bahwa konstanta sebesar 108,253, hal ini berarti jika variable independen (X1), Moderasi (Z) dan X1Z bersifat konstan maka variable kepatuhan WP (Y) sebesar 108,253. Variabel penerapan sistem e-filling memiliki nilai koefisien 1,509 dengan nilai sig 0,022. Koefisien variable pemahaman internet sebesar -2,818 dengan sig 0,000. Sedangkan koefisien variable pemoderasi (Z) yaitu interaksi antara penerapan sistem e-filling dan pemahaman internet sebesar 0,058 bekepatuhan WP dikarenakan nilai signifikannya kurang dari 0,05. Dengan kata lain pemahaman internet digunakan sebagai variable pemoderasi dalam penelitian ini.

\section{Koefisien Determinasi}

Berdasarkan hasil analisis di atas diperoleh hasil bahwa nilai $\mathrm{R}$ sebesar 0,462 sedangkan nilai R Square sebesar 0,368. Hal ini dapat diartikan bahwa pemahaman internet dapat memoderasi penerapan system e-filling sebesar $36,8 \%$ terhadap variable kepatuhan wajib pajak. Sedangkan sisanya sebesar $63,2 \%$ dipengaruhi oleh factor lain diluar penelitian ini.

\section{Uji F}

Berdasarkan table diatas diperoleh nilai $F$ sebesar 9,349. Uji ini dilakukan dengan membandingkan nilai Fhitung dengan Ftabel. Untuk mengetahui Ftabel dapat dicari dengan df1 $=\mathrm{k}-1$, df2 $=\mathrm{n}-\mathrm{k}$. Dengan sampel $(\mathrm{n})=100$ maka dapat dihitung df1 $=2-1=1$, df $2=100-2=98$, $\alpha=0,05$. Sehingga diperoleh $F$ table sebesar 3,94. Dengan demikian Fhitung $(9,349)>$ Ftabel $(3,94)$ dan nilai signifikansi 0,017 $<0,05$ sehingga dapat disimpulkan bahwa hipotesis kedua diterima.

Salah satu upaya dari Dirjen pajak dalam rangka meningkatkan kepatuhan wajib pajak yaitu dengan menerapkan system e-filling. Penerapan e-filling ini juga memberikan dampak yang positif bagi wajib pajak. Wajib pajak yang awalnya kurang patuh menjadi termotivasi dan memenuhi kewajibannya dalam pembayaran pajak. Adanya e-filling ini memberikan kemudahan dan efisiensi bagi wajib pajak dalam pelaporan 
SPT, karena wajib pajak tidak harus datang ke kantor pajak lalu mengantri lama serta menghabiskan banyak kertas untuk melaporkan SPT Tahunannya. Jika penerapan sistem e-filling semakin baik, maka kesadaran wajib pajak akan kepatuhan juga akan meningkat. Kemudahan yang dirasakan dapat berupa program e-filling yang mudah di pahami, tidak perlu antri ke KPP dan juga hemat waktu. Tujuan e-filling sendiri yaitu untuk mencapai transparansi dan menghilangkan praktik KKN.

Wajib pajak memiliki persepsi dalam penggunaan sistem $e$-filling, dimana wajib pajak menganggap bahwa sistem $e$-filling mampu memberikan manfaat serta mampu mempermudah dalam pelaksanaan kewajiban perpajakan. Sehingga akan menjadikan wajib pajak merasa puas akan penggunaan e-filling dan menjadikan wajib pajak semakin patuh. Oleh karena itu apabila penerapan e-filling semakin baik maka akan meningkatkan kepatuhan WP. Gita (2010) memberikan pendapatnya bahwa e-filling sengaja dibuat agar tidak terjadi persinggungan antara WP dengan aparat pajak serta kontrol WP bisa saja tinggi dikarenakan merekam sendiri SPTnya.

Manfaat system e-filling juga sangat dirasakan oleh KPP dimana penerimaan laporan SPT menjadi lebih cepat serta kegiatan administrasi, distribusi, pendatandan pengarsipan laporan SPT juga lebih mudah. Persepsi WP yang menyatakan bahwa e-filling mudah digunakan akan mendorong mereka untuk terus menggunakan system tersebut. Kemudahan yang diberikan sistem e-filling ini akan menyebabkan WP senang dalam menggunakannya serta membuat kepraktisan untuk WP dalam penyampaian SPT. Jika WP diberikan kemudahan dalam penyampaian SPT tahunan, maka wajib pajak akan merasakan kepuasan atas pelayanan-pelayanan yang diberikan oleh Dirjen Pajak. Wajib pajak yang memperoleh pelayanan yang baik, mudah dan tepat serta nyaman, maka wajib pajak akan merasakan puas atas kualitas pelayanan yang didapatkan sehingga akan mengakibatkan wajib pajak patuh dalam peenyampaian dan pelaporan SPT. Berdasarkan data di www.onlinepajak.com pada tahun 2018 lalu bulan maret penerimaan SPT OP meningkat hingga $14,01 \%$ menjadi 10.589 .648 . dari hasil tersebut diketahui bahwa sekitar $80 \%$ dari WP melaporkan pajaknya dengan menggunakan e-filing dan sisanya melaporkan ke KPP dalam bentuk manual. Hal ini terbukti bahwa kesadaran WP mulai meningkat dalam membayar dan melaporkan pajaknya. Kepatuhan wajib pajak ini meningkat diakibatkan karena wajib pajak mulai terbiasa dengan menggunakan sistem $e$-filling.

E-filling merupakan sistem informasi yang membantu pengguna (pembayar pajak) untuk mengirimkan laporan SPT secara online menggunakan internet dan dilakukan secara real time. Biaya serta waktu dapat diminimalkan dengan penggunaan e-filling, karena proses pelaporannya dengan menggunakan komputer yang terhubung ke internet, selain itu penyampaian laporan Surat Pemberitahuan dapat 
dilakukan kapan dan dimana saja selama jangka waktu 24 (dua puluh empat) jam sehari dan juga 7 (tujuh) hari dalam seminggu. Bahkan pada hari libur juga dapat dilakukan pelaporan SPT dengan $e$-filling .

Agar dapat menggunakan sistem e-filling, wajib pajak harus paham dan mengetahui bagaimana cara mengoperasikan internet. Jika WP tidak mampu mengoperasikan internet maka adanya penerapan system tersebut tidak memberikan dampak apa-apa terhadap kemudahan dan kenyamanan dalam proses penyampaian SPT kepada KPP yang diharapkan dapat meningkatkan kepatuhan WP. Sesuai hasil penelitian yang telah dilakukan menunjukkan bahwa pemahaman internet dapat memperkuat pengaruh penerapan system e-filling. Semakin tinggi pemahaman WP tentang internet, maka penggunaan system e-filling akan semakin tinggi pula.

\section{SIMPULAN}

Berdasakan hasil penelitian dan analisis diatas diperoh hasil bahwa penerapan sistem e-filling berpengaruh positif dan signifikan terhadap kepatuhan wajib pajak. Hal ini dapat dilihat dari nilai signifikansi sebesar 0,045 dimana nilai tersebut dibawah 0,05. Jika penerapan system e-filling semakin baik, maka kesadaran wajib pajak akan kepatuhan juga akan meningkat. Wajib pajak yang memperoleh pelayanan yang baik, mudah dan tepat serta nyaman, maka wajib pajak akan merasakan puas atas kualitas pelayanan yang didapatkan sehingga akan mengakibatkan wajib pajak patuh dalam peenyampaian dan pelaporan SPT. Selanjutnya pemahaman internet dapat memoderasi hunungan antara penerapan system e-filling terhadap kepatuhan wajib pajak. Hal ini berarti apabila pemahaman wajib pajak akan internet dalam penerapan sistem e-filling semakin tinggi maka kepatuhan wajib pajak akan semakin tinggi pula.

\section{DAFTAR PUSTAKA}

Andriani, F. D., Napitupulu, T. A., \& Haryaningsih, S. R. I. (2017). THE USER ACCEPTANCE FACTORS OF E-FILING. Journal of Theoretical And Applied Information Technology, 95(17), 4265-4272.

Ayu R, S. D., \& Hastuti, R. (2009). Persepsi Wajib Pajak: Dampak Pertentangan Diametral Pada Tax Evasion Wajib Pajak Dalam Aspek Kemungkinan Terdeteksinya Kecurangan, Keadilan, Ketepatan Pengalokasian, Teknologi Sistem Perpajakan, dan Kecenderungan Personal. (Studi Wajib Pajak Orang Pribadi. Jurnal Ilmiah Kajian Akuntansi, 1(1), 1-12.

Ghozali, I. (2011). Aplikasi Analisis Multivariate dengan Program IBM SPSSS 19 (5th ed.). Semarang: Badan Penerbit Universitas Diponegoro.

Gita, G. . (2010). Analisis Perilaku Penerimaan Wajib Pajak Terhadap Penggunaan E-Filling. Skripsi Fakultas Ekonomi Universitas Diponegoro.

Husnurrosyidah. (2016). Pengaruh Tax Amnesty Dan Sanksi Pajak Terhadap Kepatuhan Wajib Pajak di BMT se-Karesidenan Pati. Equilibrium: Jurnal Ekonomi Syariah, 4(2), 211-226. Retrieved from 
http://jurnal.syntaxliterate.co.id/index.php/syntax-

literate/article/view/90/147

Hutasoit, G. (2017). Pengaruh Tax Amnesty Terhadap Kepatuhan Wajib Pajak di Kota Palembang. Seminar Nasional Teknologi Informasi, Bisnis, Dan Desain. Retrieved from http://jurnal.syntaxliterate.co.id/index.php/syntaxliterate/article/view/90/147

Jotopurnomo, C., \& Yenni, M. (2013). Pengaruh Kesadaran Wajib Pajak, Kualitas Pelayanan Fiskus, Sanksi Perpajakan, Lingkungan Wajib Pajak Berada terhadap Kepatuhan Wajib Pajak Orang Pribadi di Surabaya. Tax Dan Accounting Revie, 1(1), 49-54.

Lado, Y. O., \& Budiantara, M. (2018). The Effect of E-Filling System Application On Civil Servant Personal Taxpayers Compliance With Internet ( A Case Study at the Department. JRAMB, 4(1), 59-84.

Moorthy, M. K., Suhaily, A., Suhaili, Syazwani, M., \& Chelliah, M. K. (2014). EFiling Behaviour among Academics in Perak State in Malaysia. Technology and Invesment, 5 (May), 79-94.

Novariyanti, R., Herawati, \& Hamdi, M. (2016). Pengaruh Penerapan Sistem E-Filling Terhadap Kepatuhan Wajib Pajak dengan Pemahaman Internet Sebagai Variabel Pemoderasi Pada KPP Pratama Bukittinggi. Ejournal Bunghatta, 9 (1), 1-14.

Nurhidayah, S. (2015). Pengaruh Penerapan Sistem E-Filling terhadap Kepatuhan Wajib Pajak dengan Pemahaman Internet Sebagai Variabel Pemoderasi pada KPP Pratama Klaten. Skripsi Fakultas Ekonomi Universitas Negeri Yogyakarta.

Rahman, A. (2010). Panduan Pelaksanaan Administrasi Perpajakan Untuk Karyawan, Pelaku Bisnis dan Perusahaan. Bandung: Nuansa.

Subadriyah, \& Aliyah, S. (2018). The Differences of Taxpayer Compliance Before and After Tax Amnesty Stimulus. Jurnal Ilmiah Bidang Akuntansi Dan Manajemen, 15(2), 15-24.

Susanto, N. . (2011). Analisis Perilaku Wajib Pajak Terhadap Penerapan Sistem E-filling Direktorat Jenderal Pajak. Universitas Indonesia.

Suyanto, Intansari, P. P. L. A., \& Endahjati, S. (2016). Tax Amnesty. Jurnal Akuntansi Fakultas Ekonomi Universitas Sarjanawiyata Tamansiswa, $4(2), 9-22$. 